\title{
Risk assessment of soil erosion by using CORINE model in the western part of Syrian Arab Republic
}

\author{
Alaa Khallouf ${ }^{1}$, Swapan Talukdar ${ }^{2}$, Endre Harsányi ${ }^{3}$, Hazem Ghassan Abdo ${ }^{4,5,6}$ and Safwan Mohammed ${ }^{3^{*}}$ (1)
}

\begin{abstract}
Background: Soil erosion is a major threat to the natural ecosystem and agricultural sector in the western part of Lattakia Governorate, Syrian Arab Republic. The main goals of this research are to investigate erosion risk by using the Coordination of Information on the Environment (CORINE) Model and to prioritize areas for conservation practices. To achieve these goals, soil samples were collected from the field, the climatic data (i.e., rainfall) and Digital Elevation Model (DEM) were obtained and utilized to perform CORINE model in Geographic Information System (GIS) environment.

Results: The results showed that only $13.2 \%$ of the study area was classified as high erodible. In addition, $45.24 \%$, $49.15 \%$ and $5.29 \%$ of the study area were under low, moderate and high actual erosion risk, respectively. This research identified slope and land use/land cover as key factors responsible for soil erosion in the study area.

Conclusions: The CORINE model acknowledged as a good tool for predicting soil erosion and highlighting the areas affected by soil erosion in the study area with high precision.
\end{abstract}

Keywords: Land degradation, CORINE, Food security, Sustainable development goals (SDGs)

\section{Background}

Besides biodiversity loss and water shortage, soil erosion considers a vital issue exacerbating the problem of food security globally [80, 81, 87]. In this sense, it has emerged that land degradation and particularly soil erosion is a big threat to food security and sustainability of agroecosystem in many parts of the world [41, 80, 81]. The current estimates indicate that soil loss is undoubtedly detrimental to worldwide food production, exacerbating a non-trivial reduce in cultivation and food production of 33.7 million tonnes [84, 86]. These numbers raise concerns about the sustainability of food security, especially in developing countries due to huge rapid

${ }^{*}$ Correspondence: safwan@agr.unideb.hu

${ }^{3}$ Institution of Land Utilization, Technology and Regional Planning, University of Debrecen, Debrecen 4032, Hungary

Full list of author information is available at the end of the article population growth, climate change, accelerated landcover/landuse change, poor land maintenance measures, epidemics, food safety and wars [2, 82, 95, 103]. However, this enhances the effective link between the importance of reducing soil erosion and sustaining global food security $[9,50,65,83]$.

In this context, the relevant scientific literature indicates that integrated agricultural management, mitigating food-related greenhouse gas emissions, and reducing erosion and rural poverty are among the most important measures to ensure food security in developing countries $[7,37,91,98]$. Moreover, the scarcity of spatial data involved in agricultural systems management poses constraints to the sustainability of global food security [48, $90,92]$. The formulation and development of spatial policies related to agricultural management constitute the cornerstone for decision-makers in the framework of sustainable land use and intensive agricultural production 
[74]. Moreover, improving dietary diversity to meet the needs of the global food market requires preserving the components of agricultural production, especially soil erosion mitigation and nutrient protection [21, 41, 80, 81]. Several socioeconomic factors influence the extent to which smallholder farmers have adopted measures to adapt to the consequences of climate change, especially in areas with a high risk of erosion [11].

Globally, rapid land degradation is one of the most serious issues because of its adverse effect on economy and eco-environment like the losses of land resources and soil productivity [104] which our society has been experiencing. One-third of the world's arable land has been lost due to soil erosion since 1970s; [89, 104]. Although the soil erosion is considered as a natural phenomenon in any part of the world, however, it is taking place through a set of processes like detachment, splashing and transportation which are accompanied by each other [29, 30, 73]. Plan Bleu [72] reported that $0.1-1 \mathrm{t} / \mathrm{ha} /$ year is the average amount of soil erosion which takes place because of natural soil erosion, while 10-1000 times faster soil erosion has been observed because of the interference of human beings. Fascinatingly, Bhange et al. [18] reported that more than 75 billion tons of soil is lost each year because of soil erosion [105], while Quinton et al. [75] estimated the total global sediment flux of about $35 \pm 10$ Pg year ${ }^{-1}$. Once the amount of soil erosion was estimated globally, it was found that most countries have been enduring from soil erosion, for example, approximately $90 \%$ of the United States croplands have experienced soil loss between 5-12 t/ha/year, while $6 \mathrm{t} / \mathrm{ha} /$ year was the soil loss from the farmlands; [99]. The Mediterranean region experiences $50 \%$ of soil erosion annually [42]. Several studies also reported that many countries of Mediterranean region had been effected by soil erosion, for instance, Portugal $[33,44,71]$, Spain $[32,78]$, Italy $[40,53$, 79], France [24, 35, 54]; Morocco [23, 34, 51]; Tunisia [38, 43, 88], and Syrian Arab Republic [1, 61, 63, 64]. Whereas more than three-quarters of Turkey's soil is found to be highly soil erosion susceptible, the UNCCD [96] reported that $72 \%$ of the Turkey's soil has been affected by soil erosion. It is very difficult to evaluate the impact of soil erosion precisely as it varies from loss of soil quality (on-site consequences), to the pollution of natural water bodies and groundwater (off-site consequences) [19, 22, 36, 47, $52,67,100]$.

Likewise, to other (Middle East and North Africa) MENA countries, soil erosion in Syrian Arab Republic is a major problem, especially in the coastal area, where the soil is shallow and the vegetation and soil cover is seriously damaged due to many factors such as intensive agriculture, unsustainable agricultural practices, deforestation, flashflood and current conflict $[2,3,56,59,60]$.
Kbibo et al. [49] reported that farm lands in the coastal area of Syrian Arab Republic (i.e., Tartous and Latakia governorates) have been suffering from drastic impact of soil water erosion, due to agricultural activities. Nevertheless, experimental studies were carried out during 2012-2013 and estimated that the amount of soil erosion ranged between $0.14 \pm 0.07$ and $0.74 \pm 0.33 \mathrm{~kg} / \mathrm{m}^{2}$ in agricultural land; whereas, the soil erosion ranged between $0.03 \pm 0.01$ and $0.24 \pm 0.10 \mathrm{~kg} / \mathrm{m}^{2}$ in the burned forest area [57]. To the best of our knowledge, Barakat et al. [15] and Barakat [16] had used CORINE model for assessment of soil erosion in Syrian Arab Republic. Unfortunately, such studies were limited to a specific basin in the Syrian Arab Republic coastal area. However, the utilization of CORINE model for assessing soil erosion is still limited in Syrian Arab Republic and needs to be employed over the country for proposing management plans. In conclusion, the main research goals are to investigate erosion risks in the western part of Latakia Governorate and to prioritize areas for conservation practices through using CORINE model.

\section{Methods \\ Study area}

The study area is located in the western part of Latakia governorate in Syrian Arab Republic, covering an area of $296 \mathrm{~km}^{2}$, between the geographical location of ${ }^{\circ} 3543^{\prime} 6.43^{\prime \prime}-{ }^{\circ} 3600^{\prime} 00^{\prime \prime} \mathrm{E}$ and ${ }^{\circ} 3537^{\prime} 32.08^{\prime \prime}-{ }^{\circ} 3529^{\prime}$ $51.98^{\prime \prime} \mathrm{N}$ as illustrated in Fig. 1. The study area is subject to the Mediterranean climate and is placed in the 1st agro-ecological zone (i.e., rainfall over $600 \mathrm{~mm}$ ), as other costal part of Syrian Arab Republic [55]. Generally, the precipitation occurs from September to May, with the highest amount in January $(75-120 \mathrm{~mm})$. The average temperature ranges between $17.2^{\circ}$ and $22.3^{\circ} \mathrm{C}$. The study area is characterized by diversified landforms types such as coastal plain, medium heights hills, and alluvial plain (lower part of the basin). The highest elevation of the study area is $267 \mathrm{~m}$. above sea level.

The main economic activity in the area of study is agricultural activities, where the common agricultural crops are wheat, citrus and olive (Fig. 2). Moreover, several types of vegetation such as Ceratonia siliqua, Pistacia lentiscus, and Inula viscosa dominate the study area.

\section{Soil samples and analysis}

The soil properties are most important factors for CORINE model. Therefore, in this study, a field survey was conducted to collect soil samples (Fig. 3). Soil and land cover characteristics were described for each location. Stoniness and soil depth were measured. Soil physical and chemical properties like texture, organic matter (OM in percentage), $\mathrm{pH}$, electrical conductivity (EC), 

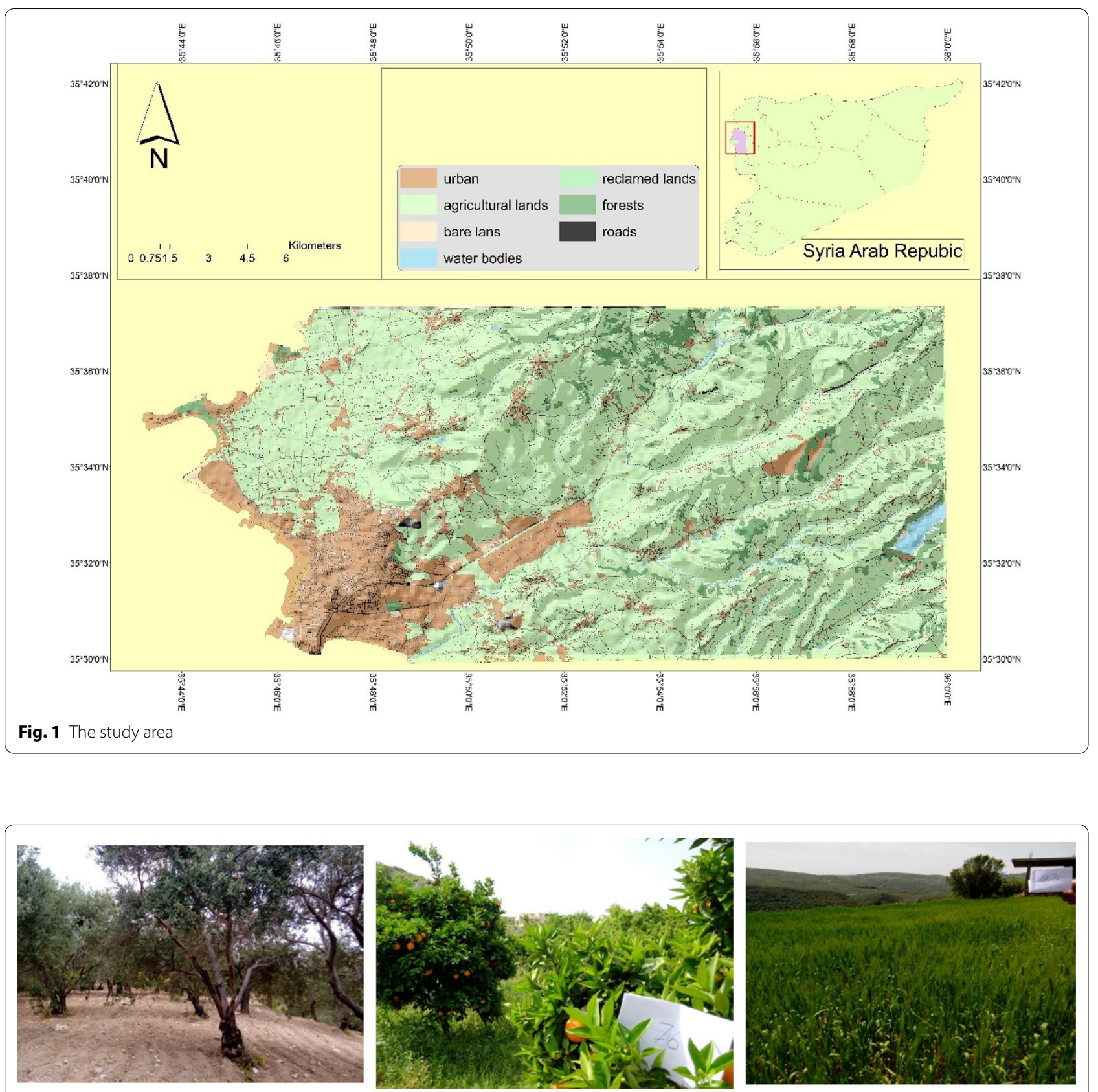

Fig. 2 Agricultural crops

cation exchange capacity (CEC) and calcium carbonate $\left(\mathrm{CaCO}_{3}\right.$ in percentage) were estimated from collected soil samples in soil science laboratory.

\section{Theoretical background of CORINE model}

In 1985, the CORINE programme was lanced by the European Union (EU) for land observation and monitoring, which primarily used for land cover/land use mapping and monitoring in the EU [25]. In a later stage, the
CORINE database was used for multidisciplinary purposes, which served as a main input for mapping soil erosion risk $[69,70]$, soil organic carbon $[6,8]$, transitional landscapes [97], and land use change [25].

The well-known CORINE model is one of the semiqualitative cartographic methods that can easily be integrated with GIS environment to utilize and process remote sensing (RS) data [104]. The CORINE model can be employed for determining (soil erosion) SR 


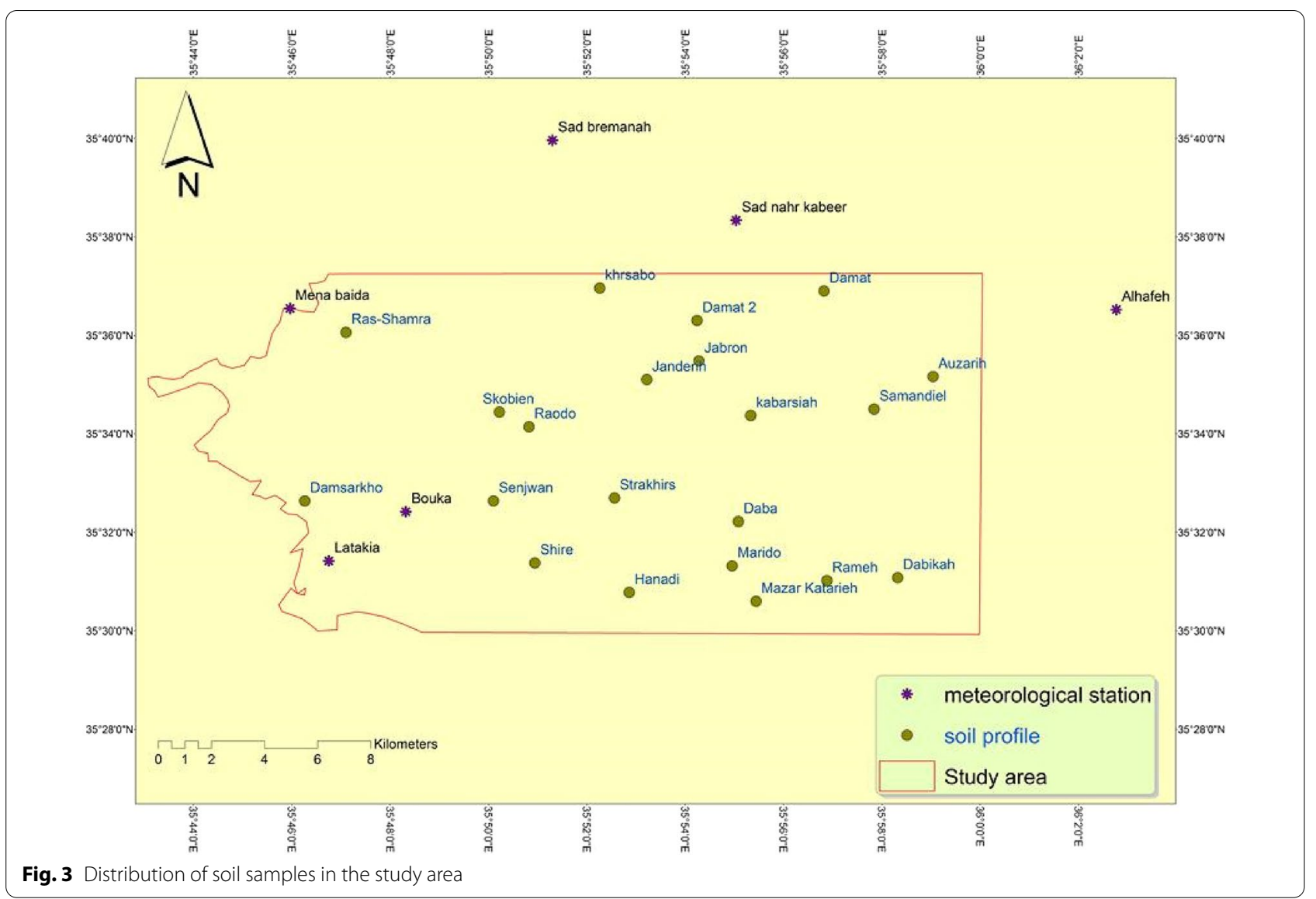

based on universal soil loss equation (USLE) [77]. The other advantage of the CORINE model is the ability to map the potential soil erosion risk (PSER) and the actual soil erosion risk (ASRR) in lucrative way [13]. Within CORINE framework, the PSER has been computed based on rainfall erosivity, soil erodibility, and topography, while the ASRR has been estimated based on PSER and vegetation cover. Nevertheless, PSER and ASRR are necessary tools for hydrologists and catchment managers, because they play a vital role in any catchment development plan.

Generally, CORINE model is widely used due to its simplicity; flexibility and efficiency compared with physical-based models (i.e., WEPP; EPIC), which need high input data as well as broad field information assortment [10, 76, 104]. Many researchers all over the world, especially in Europe and the Mediterranean region used CORINE model in order to identify the widely exposed area to soil erosion, such as Turkey [13, 17, 76, 101]), Iran [94], China [104], Lebanon [85], Egypt [31]; Morocco [46] and many other parts of the world.

\section{The CORINE model framework for erosion risk assessment} The soil erodibility (SE), rainfall erosivity (RE), land use land cover (LULC) and slope (S) were prepared for modeling the CORINE model. Soil depth, stoniness and texture maps were prepared using Inverse Distance Weight (IDW) method based on the data collected from the field and from the laboratory analysis to produce SE map. The RE calculated based on meteorological data. The Landsat image was used to produce LULC map, while the DEM was used for producing slope map. Based on CORINE approach, the PSER was estimated by overlying the SE, RE, and S layers; while merging between PSER and LULC produce the ASRR (Fig. 4).

\section{Soil erodibility index (SE)}

The SE reflects the stability of soil aggregation against the erosion processes. The SE is strongly correlated with the soil aggregate stability and the shear strength $[20,28,102]$. Eq. 1 was used to calculate the soil erodibility factor (SE):

$$
\mathrm{SE}=\text { Texture class } * \text { depth class } * \text { stoniness class, }
$$




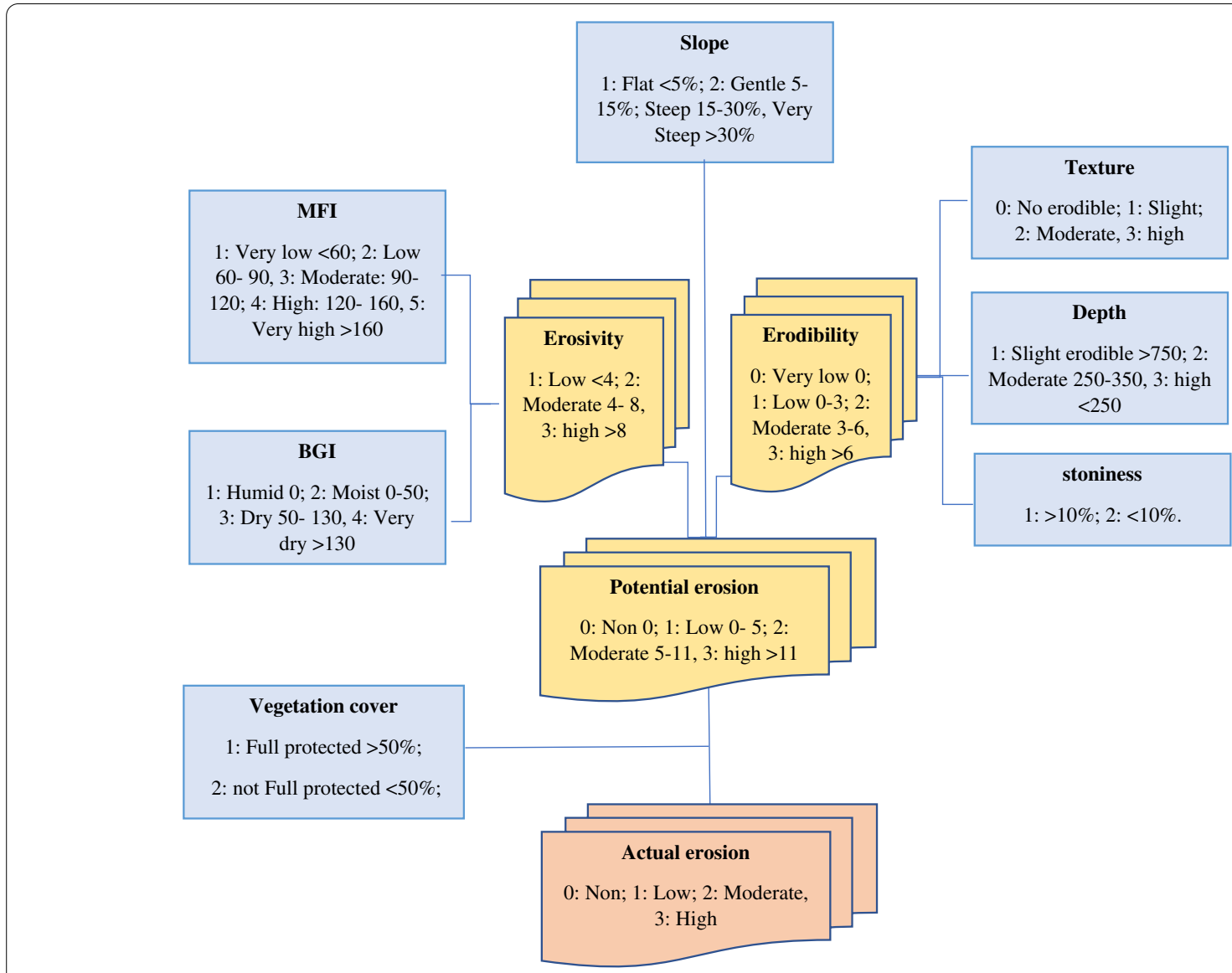

Fig. 4 Flowchart of CORINE model

where texture class; depth class and stoniness class can be defined by Fig. 4 .

\section{Rainfall erosivity index (RE)}

The RE is the ability of raindrops to destroy soil aggregates and then caused erosion [66]. The climatic data were collected from 6 meteorological stations during 1986-2016 as described in Table 1. Generally, the erosivity is a computation between the Modified Fournier Index (MFI) [12] and the Bagnouls-Gaussen Aridity Index (BGI) [14]. The MFI was computed using Eq. 2:

$$
\text { MFI }=\sum_{i=1}^{12} \frac{(\text { Monthly precipitation })^{2}}{\text { Mean anual precipitation }}
$$

Similarly, BGI was computed using Eq. 3:

Table 1 Characterization of meteorological stations and BGI and MFI values

\begin{tabular}{lllllllrr}
\hline Station & $X$ & $Y$ & Average rainfall & $\begin{array}{l}\text { Average } \\
\text { temperature }\end{array}$ & Max T & Min T & BGl & MFI \\
\hline Sad Nahr Kabeer & 35.91722 & 35.64 & 788.9 & 19.15 & 24.7 & 13.6 & 102.631 & 120.6409 \\
Alhafeh & 36.04611 & 35.61 & 1049.2 & 17.4 & 20.7 & 14.1 & 34.117 & 138.8918 \\
Latakia & 35.77917 & 35.52 & 713.6 & 20.6 & 24.9 & 16.2 & 120.409 & 102.6655 \\
Bouka & 35.80528 & 35.54 & 835.3 & 20 & 25.4 & 14.6 & 93.866 & 122.8693 \\
Mena Baida & 35.766 & 35.61 & 797.7 & 22.35 & 29.6 & 15.1 & 108.676 & 114.0132 \\
Sad Bremanah & 35.855 & 35.67 & 886.2 & 20.05 & 24.7 & 15.3 & 98.355 & 118.8277 \\
\hline
\end{tabular}




$$
\mathrm{BGI}=\sum_{i=12}^{12}\left(2 t_{i}-P_{i}\right) K_{i},
$$

where $t_{i}$ is the mean temperature; $P_{i}$ is the total precipitation; $K_{i}$ is the part of the month and $2 t_{i}-P_{i}>0$.

After calculating MFI and BGI, the generated results were reclassified according to [26] as shown in Figs. 5 and 6.

\section{Slope (S)}

In the Mediterranean region, the topography plays an important role in soil erosion especially with poor vegetation [68]. The DEM of the study area was obtained from https://earthexplorer.usgs.gov/ with the spatial resolution of $30 \mathrm{~m}$. the slope was produced and then reclassified according to CORINE [26].

\section{Vegetation cover}

The Landsat 8OLI image was downloaded from USGS earth explorer and used for extracting vegetation of the study area. The Normalized Differential Vegetation Index was estimated using Eq. 4:

$$
\mathrm{NDVI}=\frac{\mathrm{NIR}-\mathrm{VIS}}{\mathrm{NIR}+\mathrm{VIS}}
$$

where the VIS and NIR represent the spectral reflectance measurements acquired in the visible and near-infrared regions of electromagnetic wave spectrum, respectively [94]. Hence, the NDVI values range between 1 and -1 . The results were rescaled to $0-100$ and then reclassified (more than $50 \%$ was considered as fully protected, and less than $50 \%$ was considered as not fully protected).

In the ultimate stage, the PSER and ASRR maps were produced by overlaying all input layers over each other.

\section{Results}

\section{Soil characteristics}

According to the United States Department of Agriculture Soil (USDA) Taxonomy (2010), two major soil orders have been detected in the study area, as previously reported by Ghanem et al. [39]. The first one is Entisols, which has been divided into the following sub-groups: Typic xerorthents, Lithic xerorthents and Typic xerofluvents. While, the second one is Inceptisols, which has been divided into the following sub- groups: Typic Calcixerepts; Lithic Calcixerepts, and Calcic Haploxerepts. The general feature of each unit is illustrated in Table 2, while the physical and chemical properties can be seen in Table 3.

Based on findings of soil depth analysis, the overall soil depth of the study area can be considered as good ranging between 25 and $75 \mathrm{~cm}$ that indicates the development of weathering processes have been going on. Meanwhile, the clay content ranges between 34 and $50 \%$, thus, most of the studied profiles have a good

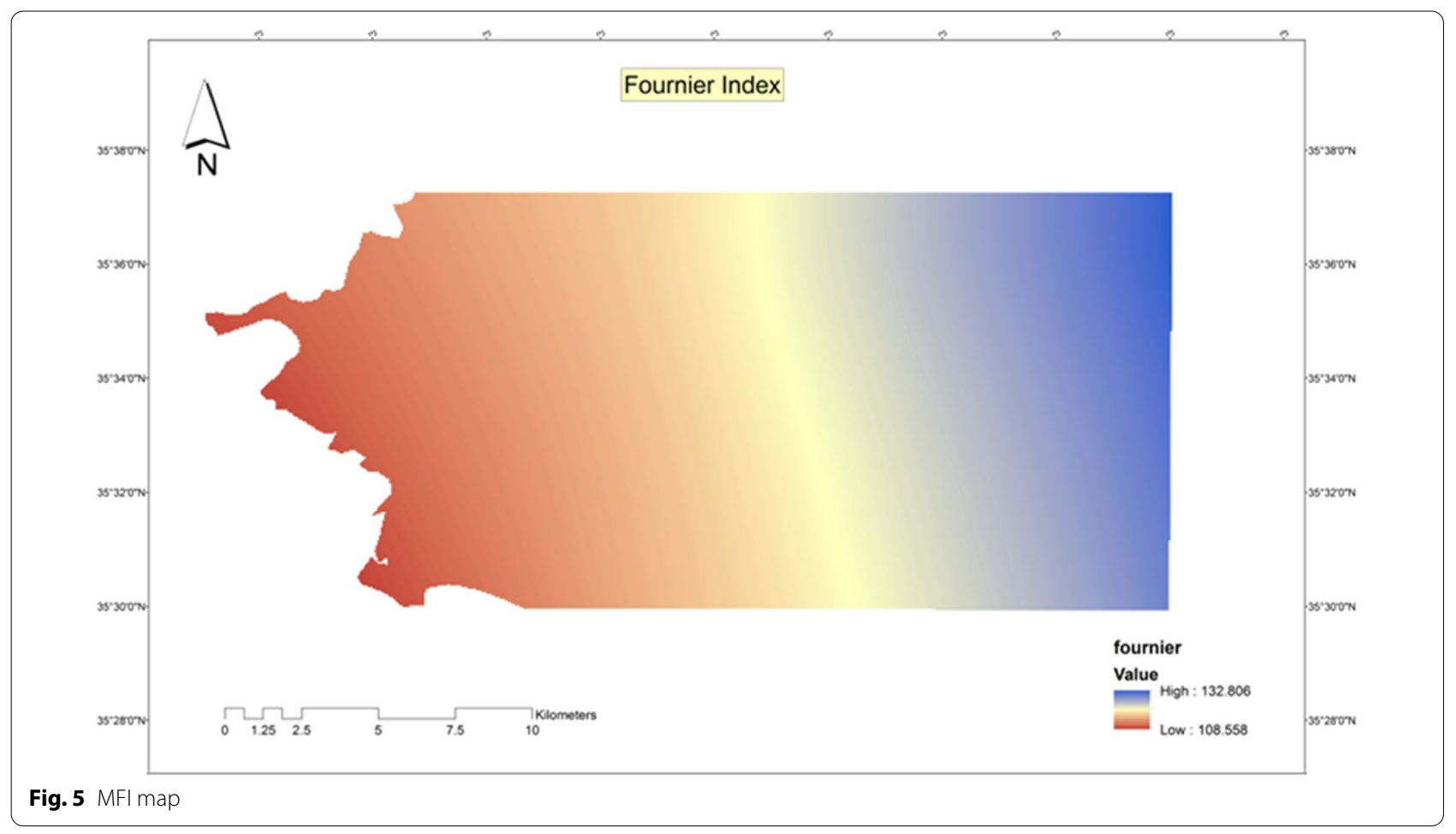




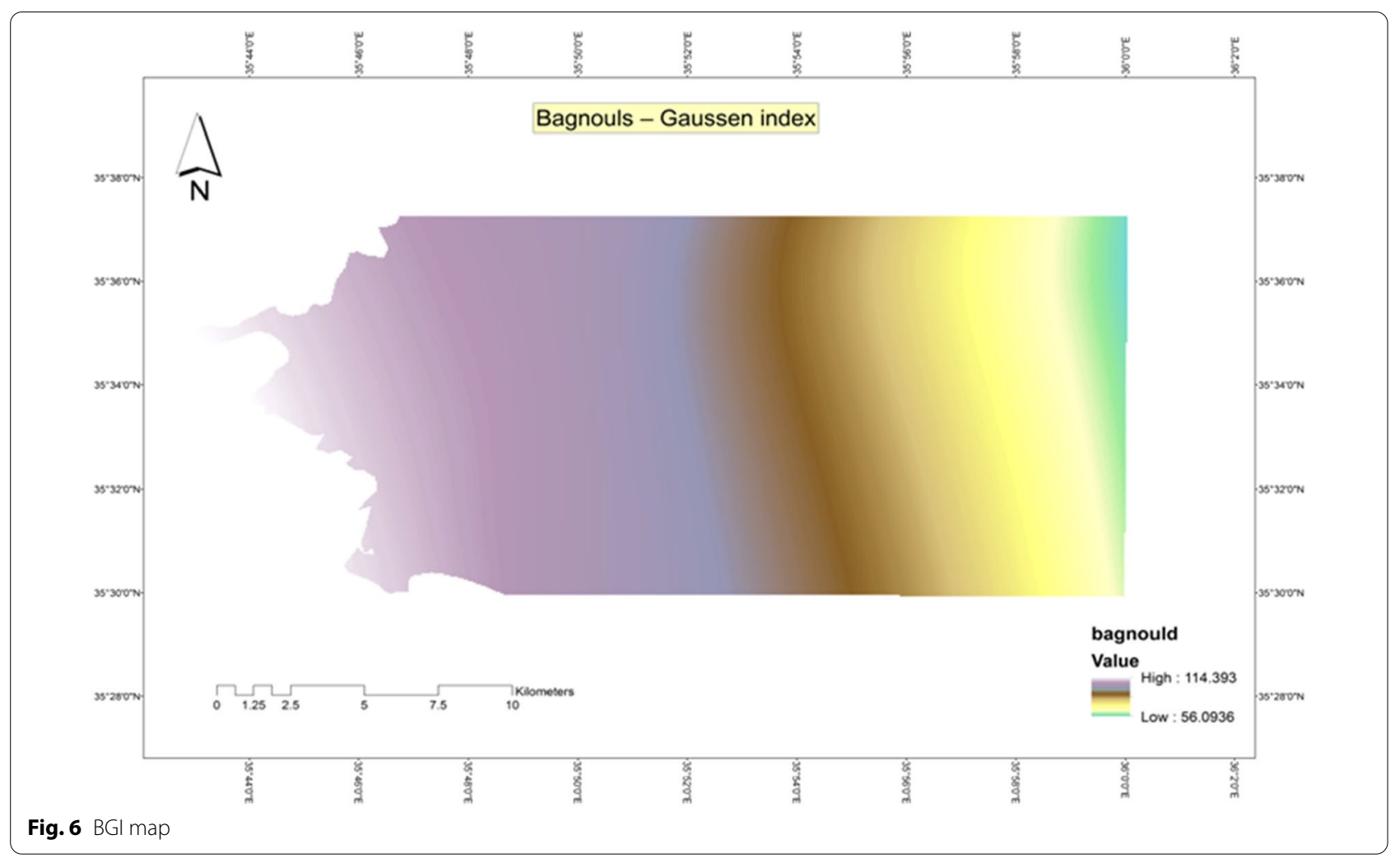

Table 2 The general features of each soil sub-group

\begin{tabular}{|c|c|c|c|c|c|c|}
\hline Land unit & Soil sub-t group & Area (\%) & Elevation (m) & Slope (\%) & Stoniness (\%) & Land use type \\
\hline \multirow[t]{2}{*}{$c l p$} & Typic Calcixerepts & 15.8 & $0-50$ & 5 & 15 & Citrus \\
\hline & & & & & & Olive \\
\hline \multirow[t]{2}{*}{ val } & Typic xerofluvents & 20.01 & $25-50$ & $5-8$ & $8-12$ & Citrus \\
\hline & & & & & & Olive \\
\hline \multirow[t]{2}{*}{ gslo } & Typic Calcixerepts & 27.27 & $25-150$ & $8-15$ & 15 & Olive \\
\hline & & & & & & Cereal \\
\hline \multirow[t]{2}{*}{ mslo } & Typic xerorthents & 15.58 & $75-225$ & $15-30$ & $15-30$ & Olive \\
\hline & & & & & & Forest \\
\hline \multirow[t]{2}{*}{ sslo } & Lithic xerorthents & 4.6 & $75-200$ & $>30$ & 35 & Olive \\
\hline & & & & & & Forest \\
\hline \multirow[t]{2}{*}{$s / p$} & Calcic Haploxerepts & 7.9 & $75-275$ & $8-15$ & $5-15$ & Olive \\
\hline & & & & & & Citrus \\
\hline
\end{tabular}

percentage of clay content. The findings of the $\mathrm{pH}$ test indicate that the soil of the study area can be considered as mildly alkaline (the $\mathrm{pH}$ ranges between 7.9 and 8.5). The EC value of soil was less than $0.4 \mu \mathrm{S} \cdot \mathrm{cm}^{-1}$ with low content of organic matter $(0.8-1 \%)$ and high content of $\mathrm{CaCO}_{3}$.

\section{PSER}

The soil erodibility reflects the soil resistance to erosion factors such as raindrops forces and runoff [20]. Thus, the soil erodibility measurement is very important for studies on soil erosion and land use planning. The findings indicate that almost $56 \%$ of the study area contained a good 
amount of clay content (i.e., C, CS, SiC) which suggest high resistance to soil water erosion due to the stability of soil aggregates. While only $15 \%$ of the study area was under high erosion risk hazard due to high loamy content (i.e., $\mathrm{L}, \mathrm{Sil}, \mathrm{Si}, \mathrm{SL}$ ). To sum that, $56 \%$ of the study area is in class 1 , according to texture classification, while $62 \%$ is in class 1 , according to depth classification; and $58 \%$ of the

Table 3 The physical and chemical properties of each soil sub-group

\begin{tabular}{lllllllll}
\hline Land unit & Ec dS $/ \mathrm{m}$ & $\mathrm{pH}$ & $\mathrm{CEC}$ cmol/kg & CaCO3\% & OM \% & Clay \% & Silt \% & Texture \\
\hline clp & 0.36 & 8.2 & 38.5 & 35.70 & 1.130 & 43.93 & 29.75 & Clay \\
val & 0.703 & 7.82 & 25.15 & 43.30 & 0.907 & 36.90 & 23.90 & Clay loam \\
gslo & 0.57 & 8.12 & 36.28 & 50.53 & 1.075 & 34.15 & 29.69 & Clay loam \\
mslo & 0.47 & 8.4 & 32.89 & 47.15 & 0.880 & 50.39 & 30.11 & Clay \\
sslo & 0.37 & 7.79 & 34.49 & 62.80 & 0.990 & 43.96 & 42.49 & Silty clay \\
slp & 0.35 & 8.29 & 38.79 & 48.60 & 0.800 & 38.52 & 34.52 & Clay loam \\
\hline
\end{tabular}

Table 4 Distribution of soil erodibility factors

\begin{tabular}{|c|c|c|c|c|c|c|c|c|}
\hline \multicolumn{3}{|c|}{ Soil texture } & \multicolumn{3}{|c|}{ Soil depth } & \multicolumn{3}{|c|}{ Stoniness } \\
\hline & Class & $\%$ & & Class & $\%$ & & Class & $\%$ \\
\hline 1 & $\mathrm{C}, \mathrm{CS}, \mathrm{SiC}$ & 55.74 & 1 & 75 & 61.8 & 1 & $>10 \%$ & 42.5 \\
\hline 2 & $\mathrm{SCL}, \mathrm{CL}, \mathrm{S}, \mathrm{LS}, \mathrm{SiCL}$ & 29.6 & 2 & $75-25$ & 32.5 & 2 & $<10 \%$ & 57.5 \\
\hline 3 & L, Sil, Si, SL & 14.66 & 3 & 25 & 5.7 & & & \\
\hline
\end{tabular}

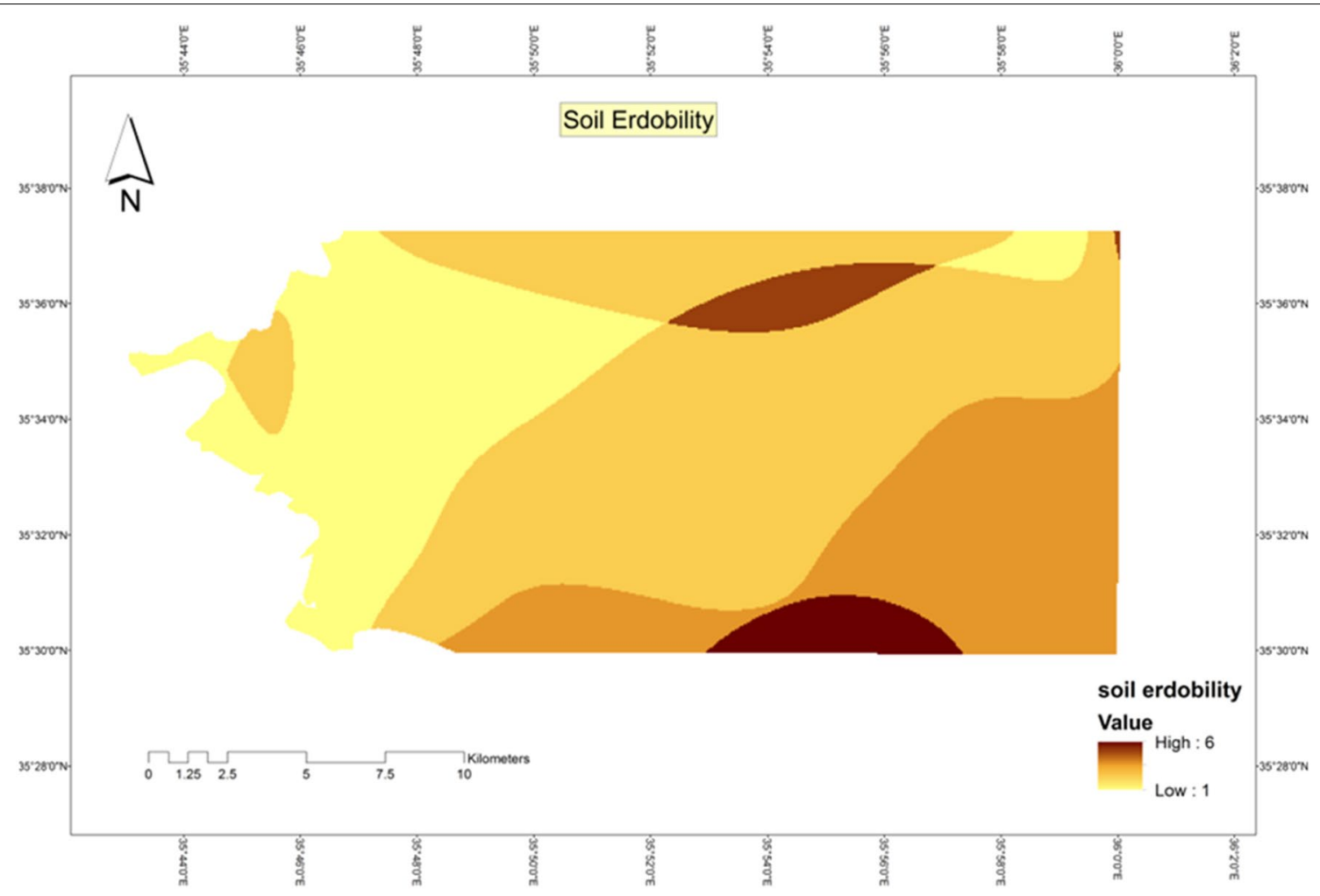

Fig. 7 Soil erodibility index 
study sites have stoniness with less than 10\% (Table 4). The final map of erodibility is shown in Fig. 7.

Figure 8 shows the distribution of erosivity index in the study area. The majority of the study area was under class 3 (more than 8), indicating the impact of rainfall in the study area. Particularly the erosivity index tends to be stronger (blue area) toward the eastern part, which can be explained by the effect of topography (mountain).

Undoubtedly, the slope plays a vital role in soil erosion [27]. Higher the slope represents higher the chances of soil erosion (under the same land cover) [93]. Figure 9 and Table 5 show that only $30 \%$ of the study area has slope more than $15 \%$, which could be easily enhanced runoff and increased the probability of soil water erosion occurrences. Nevertheless, the higher slope (red color of Fig. 9) area is located in the northern and eastern part of the study area which could be considered as a potential location subjected to erosion unless there was a good land cover, as revealed from Fig. 9. The PSER was prepared by integrating mentioned data layers and the generated PSER was used as a key input for ASRR modeling.

\section{ASRR}

Generally, the study area has been characterized by the mixed agroecosystem indicates the combination of different land use such as agricultural activities and forestry.
Thus, high erosion rate is expected from cultivated areas, while forest areas have good protection for soil. The NDVI map showed the intensity of vegetation cover of the study area, which ranges from -0.13 to 0.38 (Fig. 10). The findings of vegetation cover reported that $70 \%$ of the study area was classified as fully protected (i.e., forest); while $30 \%$ was not protected which could be an agricultural land or burned forest (Table 5).

In the ultimate stage, the ASRR model was generated by overlaying the LULC map and PSER map (Fig. 11). However, the result of ASRR model reported that $57 \%$ of the total study area is under the moderate and high erosion risk zones, whereas, $43 \%$ of the study area is under the low erosion risk zone.

\section{Discussion}

\section{Output of CORINE model in the coastal area of Syrian Arab Republic}

This study attempted to utilize the CORINE model in the coastal region of Syrian Arab Republic, which is considered as a promising tool for future conservation plans, as the decision-makers were able to identify the vulnerable area to soil water erosion by adopting such approach.

Strictly speaking, Fig. 11 demonstrates that the eastern and northern part of the study area were under the moderately and highly prone to soil erosion risk

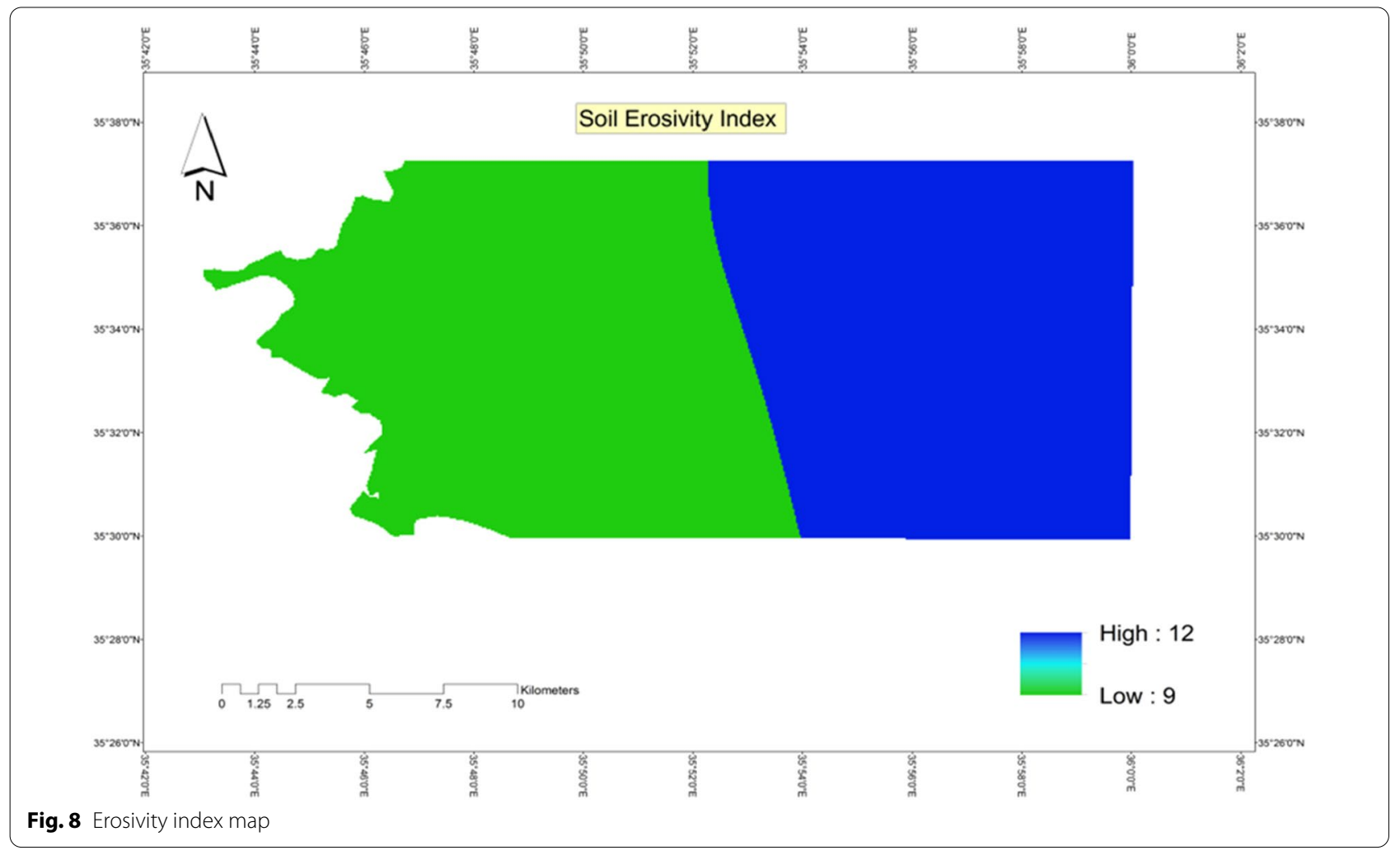




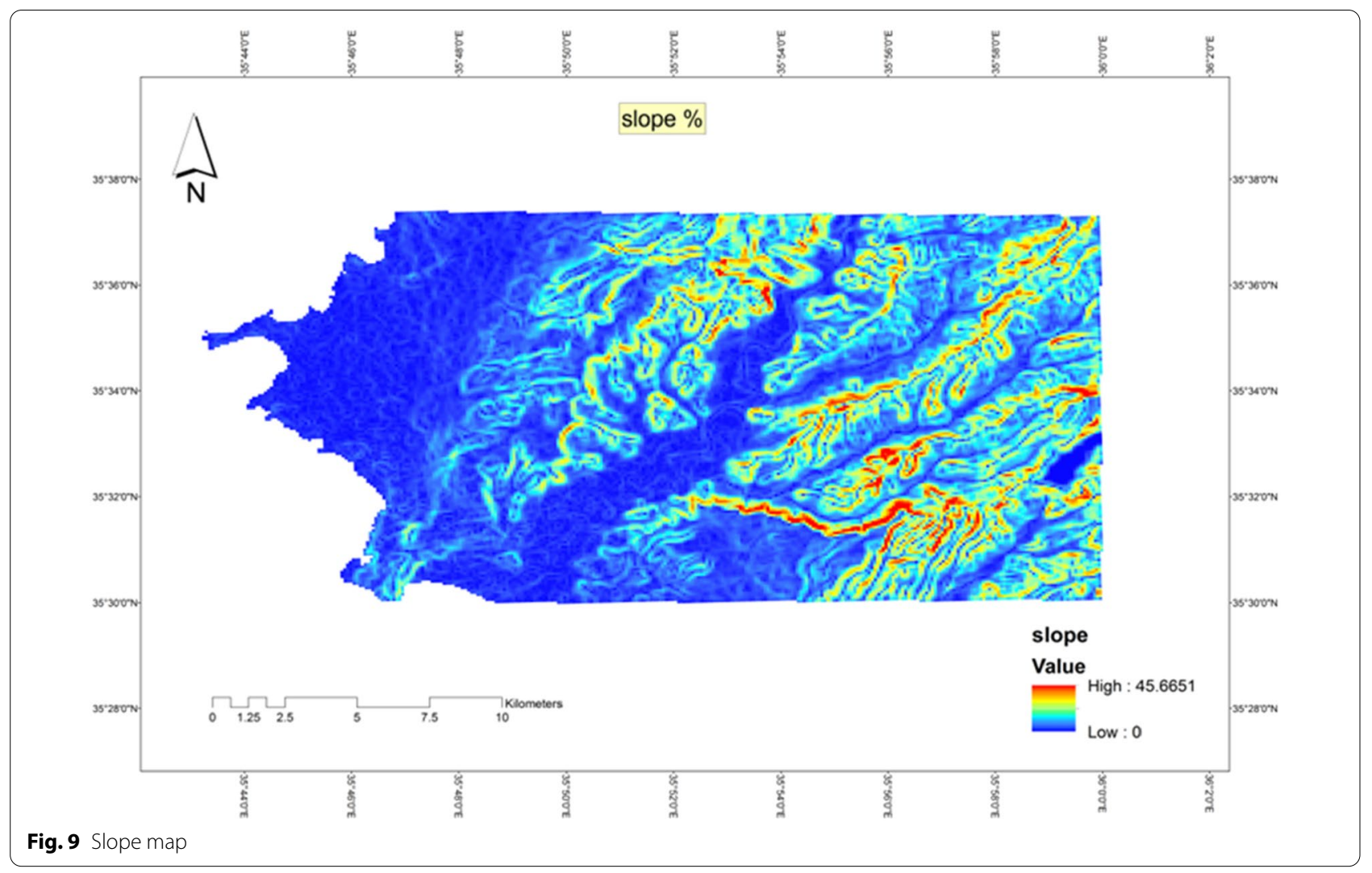

Table 5 Spatial distribution of slope, land cover, and actual erosion risk

\begin{tabular}{|c|c|c|c|c|c|c|c|c|}
\hline \multicolumn{3}{|c|}{ Slope } & \multicolumn{3}{|c|}{ Land cover } & \multicolumn{3}{|c|}{ Actual erosion risk } \\
\hline & Class & $\%$ & & Class & $\%$ & Class & Area km² & $\%$ \\
\hline 1 & $<5$ & 15.8 & 1 & $\mathrm{~F}$ & 69.4 & low & 130.8 & 45.24 \\
\hline 2 & $5-15$ & 55.1 & 2 & $\mathrm{nF}$ & 30.6 & moderate & 142.1 & 49.15 \\
\hline 3 & $15-30$ & 24.42 & & & & high & 15.3 & 5.29 \\
\hline 4 & $>30$ & 4.6 & & & & & & \\
\hline
\end{tabular}

(red and purple area) zones; while the erosion was less pronounced in the northwest part (green area) of the study area. Hence, soil erodibility (Fig. 7) and ASER (Fig. 11) reveal that the area having high erodibility value (brown area in Fig. 7) was the main distinguished area with high susceptibility to erosion hazard (purple area in Fig. 11). Except the high erosion-prone area, the erosion hazard was the final outcome of interaction between rainfall erosivity, sharp slope, and land cover. However, the areas, where the traditional agricultural activities have been highly dominated, were highly susceptible to soil erosion as can be found in vegetation map of the study area (Fig. 10) and field observation.
On the other hand, only $13.6 \%$ of the study area was classified as high erodible, while the rest of the study area was under moderate or low erodible. Such kind of result can be produced because of the presence of high content of clay and bounded with OM (\%), resulting in the stable soil aggregates against raindrops and runoff. However, the land cover and slope are the most dominating factors which are responsible for making the study area as the highly soil erosion zone. Furthermore, the present study showed that the findings are identical with the work of Abdo and Salloum [4, 5, 16] and Barkat [16] who studied the erosion in the coastal region of Syrian Arab Republic and stressed the important role of topography 

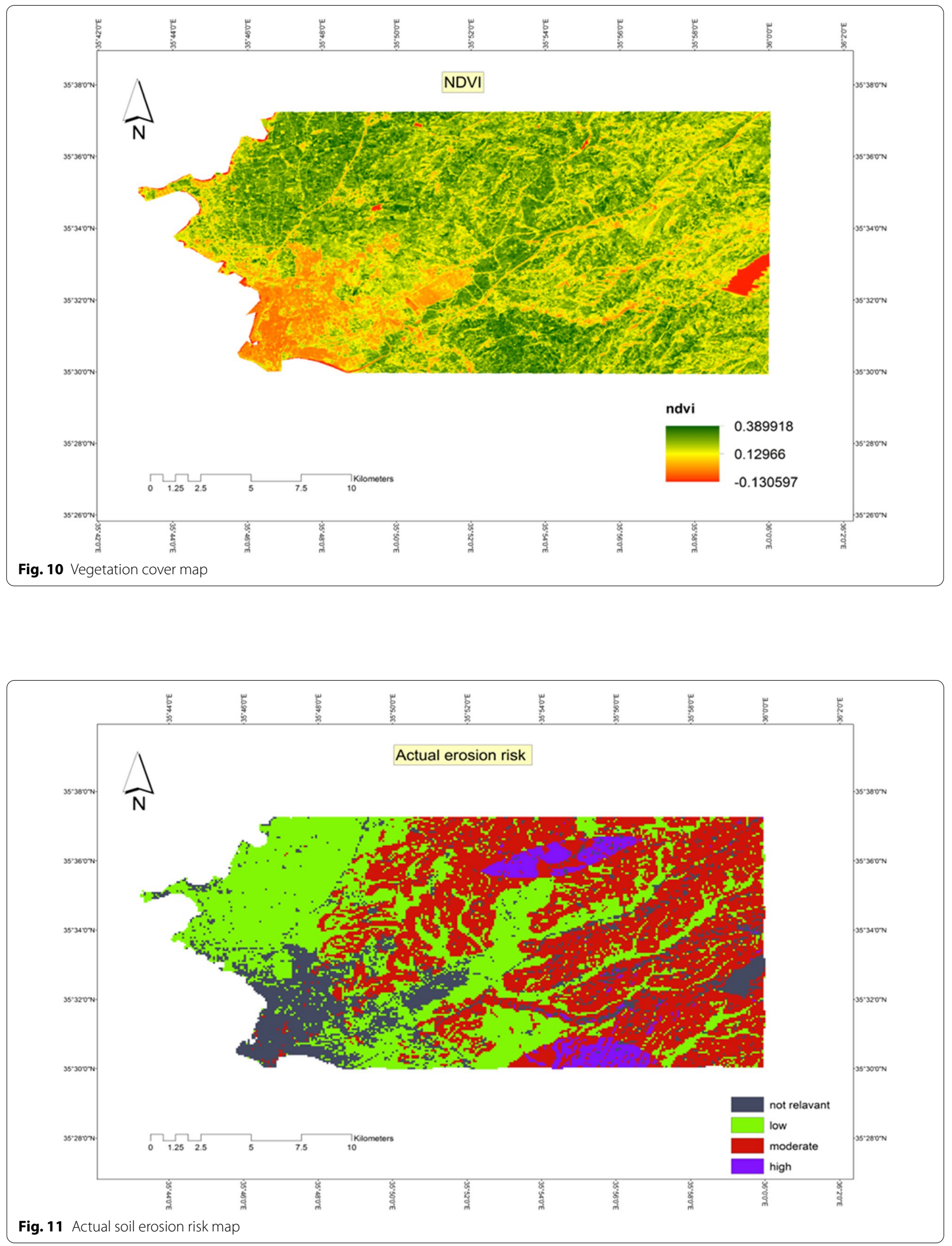
in soil erosion. Similarly, Hussien [45] and Mohammed et al. [57, 58, 62] highlighted on how land use land cover affects soil erosion in Syrian Arab Republic, especially in coastal part.

The fundamental difference between PSER and ASRR models is that the ASRR model evaluate the impact of LULC on soil erosion. Thus, the erosion risk is always higher in PSER maps [104]. Within this context, this study was conducted before the massive wildfires that happened in summer 2019 in the coastal region of Syrian Arab Republic. Therefore, the results of the present study (i.e., ASRR) were subjected to be changed due to the drastic change of LULC. Interestingly, the PSER map could serve as the database for proposing rehabilitation plan in the study area.

\section{Limitations and strengths of CORINE approach in the coastal area of Syrian Arab Republic}

The limitation of the present study is the nonexistence of any kinds of quantitative studies that measure soil erosion. Thus, the reliability of CORINE model in the coastal area is still questionable. Even though, most of the input files were trustworthy, as they were obtained from international data set (i.e., DEM, Landsat- 8 image). Some of the parameters were directly collected from the field (soil depth, stoniness) and others were generated in soil laboratory (soil texture). However, the validation of the prepared model is mandatory, otherwise, they will not be reliable any more. Yet, only WEPP model was calibrated and validated $[63,64]$, while the rest of the models which were applied in Syrian Arab Republic such as RUSLE $[4,5,61]$, and CORINE model [16] were never validated. Nevertheless, one of the advantages of CORINE approach is the availability of data for the majority of the indices. However, CORINE model could be a promising tool for managing future land degradation by highlighting the most vulnerable area to soil erosion (at least in the Syrian Arab Republic).

The accelerated soil erosion in a developing country like Syria will threaten food security in the long term, especially in the coastal region. Although the coastal area of Syria is considered as a first agroecosystem area, the intensive soil erosion requires integrated management, which guarantees the improvement of rural livelihoods in particular. Meanwhile, the increasing demand for food in the coastal region, with more than $20 \%$ of the Syrian population, constitutes an additional factor on food security in light of the danger of severe erosion, climate change and the current living and economic consequences caused by the ongoing war. Following agricultural rotations, promoting environmental agriculture, landscape management, establishing terraces, establishing and implementing the agricultural policies and adopting modern cultivation methods, creating a long-term, highquality climate and soil databases are among the most important measures for managing the soil erosion risks in the coastal region of Syria. In this regard, Mohammed et al. [62] reported that planting the slopes of the coastal area with leguminous crops reduce runoff flows and erosion rates. However, the integration between geospatial techniques and experimental models provides a constructive platform with effective spatial results in identifying areas with higher levels of erosion, hence starting to implement maintenance and protection measures, thus enhancing food security in the area.

\section{Concluding remarks}

The present work was mainly focused on predicting soil water erosion zone using CORINE approach by integrating field survey and remote sensing data in the western part of Syrian Arab Republic. The key findings of this study can be summarized, as follows:

- Almost $45 \%$ of the study area was under tolerant erosion rate.

- More than $55 \%$ of the study area was under moderate and high actual erosion risk, where the urgent conservation plans should be implemented to minimize the predicted high soil erosion zone.

- The conservation plan should be taken by the local authority in collaboration with local farmers to eliminate or minimize the soil erosion, which will have an ultimate good impact on both environment and local communities.

The CORINE approach is a good tool for predicting and highlighting the most widely erosion-affected areas, as well as saving time and money. On the other hand, the accuracy of any model is an essential issue for readability and reliability of results.

\section{Acknowledgements \\ Authors would like to thank General Commission for Scientific Agricultural Research (GCSAR) (Syria), and Debrecen University (Hungary) for their unlim- ited support.}

\section{Authors' contributions}

Writing original draft: SM. Mapping: AK. Review writing: HA, EH, ST. All authors read and approved the final manuscript.

Funding

Open Access funding provided by University of Debrecen.

Availability of data and materials

Available upon request.

Declarations

Ethics approval and consent to participate Not applicable. 


\section{Consent for publication \\ Not applicable.}

\section{Competing interests}

Not applicable.

\begin{abstract}
Author details
1 Department of Natural Resources Management, General Commission for Scientific Agricultural Research (GCSAR), Damascus, Syrian Arab Republic. ${ }^{2}$ Dept. of Geography, University of Gour Banga, Malda, India. ${ }^{3}$ Institution of Land Utilization, Technology and Regional Planning, University of Debrecen, Debrecen 4032, Hungary. ${ }^{4}$ Geography Department, Faculty of Arts and Humanities, Tartous University, Tartous, Syria. ${ }^{5}$ Geography Department, Faculty of Arts and Humanities, Damascus University, Damascus, Syria. ${ }^{6}$ Geography Department, Faculty of Arts and Humanities, Tishreen University, Lattakia, Syria.
\end{abstract}

\section{Received: 10 November 2020 Accepted: 16 February 2021}

Published online: 28 July 2021

\section{References}

1. Abdo HG. Geo-modeling approach to predicting of erosion risks utiliz ing RS and GIS data: a case study of Al-Hussain Basin Tartous, Syria. J Environ Geol. 2019;1(1):1-4.

2. Abdo HG. Impacts of war in Syria on vegetation dynamics and erosion risks in Safita area, Tartous Syria. Regional Environ Change. 2018;18(6):1707-19.

3. Abdo HG. Evolving a total-evaluation map of flash flood hazard for hydro-prioritization based on geohydromorphometric parameters and GIS-RS manner in Al-Hussain river basin, Tartous Syria. Nat Hazards. 2020;104(1):681-703.

4. Abdo H, Salloum J. Mapping the soil loss in Marqya basin: Syria using RUSLE model in GIS and RS techniques. Environ Earth Sci. 2017;76(3):114.

5. Abdo H, Salloum J. Spatial assessment of soil erosion in Alqerdaha basin (Syria). Model Earth Syst Environ. 2017;3(1):26.

6. Adhikari K, Hartemink AE, Minasny B, Kheir RB, Greve MB, Greve MH. Digital mapping of soil organic carbon contents and stocks in Denmark. PLoS ONE. 2014;9(8):e105519.

7. Agidew AMA, Singh KN. The implications of land use and land cover changes for rural household food insecurity in the Northeastern highlands of Ethiopia: the case of the Teleyayen sub-watershed. Agric Food Secur. 2017;6(1):1-14.

8. Aksoy E, Yigini Y, Montanarella L. Combining soil databases for topsoil organic carbon mapping in Europe. PLoS ONE. 2016;11(3):e0152098.

9. Alemu ZA, Ahmed AA, Yalew AW, Simanie B. Spatial variations of household food insecurity in East Gojjam Zone, Amhara Region, Ethiopia: implications for agroecosystem-based interventions. Agric Food Secur. 2017;6(1):36.

10. Al-Sayah MJ, Nedjai R, Abdallah C, Khouri M, Darwish T, Pinet F. Evaluating differences of erosion patterns in natural and anthropogenic basins through scenario testing: a case study of the Claise, France and Nahr Ibrahim Lebanon. In Soil Erosion. Rijeka: IntechOpen; 2019.

11. Amare A, Simane B. Determinants of smallholder farmers' decision to adopt adaptation options to climate change and variability in the Muger Sub basin of the Upper Blue Nile basin of Ethiopia. Agric Food Secur. 2017:6(1):1-20.

12. Arnoldus HMJ (1980) An approximation of the rainfall factor in the Universal Soil Loss Equation. An approximation of the rainfall factor in the Universal Soil Loss Equation, p. 127-132.

13. Aydın A, Tecimen HB. Temporal soil erosion risk evaluation: a CORINE methodology application at Elmalı dam watershed Istanbul. Environ Earth Sci. 2010;61(7):1457-65.

14. Bagnouls F, Gaussen H. Les climats biologiques et leur classification. In: Annales de géographie, No. 355, vol. 66. Paris: Armand Colin; 1957. p. 193-220.

15. Barakat M, Mahfoud I, Kwyes AA. Study of soil erosion risk in the basin of Northern Al-Kabeer river at Lattakia-Syria using remote sensing and GIS techniques. Mesopotamian J Mar Sci. 2014;29(1):29-44.
16. Barkat M. Prediction of spatial distribution of water erosion risk in Bhmra Basin Dam soil using Corine model. Tishreen Univ J Res Sci Stud Biol Sci Ser. 2017;39:39-43 (In Arabic).

17. Bayramin I, Erpul G, Erdoğan HE. Use of CORINE methodology to assess soil erosion risk in the semi-arid area of Beypazari, Ankara. Turk J Agric For. 2006;30(2):81-100.

18. Bhange HN, Deshmukh VV. A RS and GIS approaches for the estimation of runoff and soil erosion in SA-13 watershed. In: Hydrologic modeling. Singapore: Springer; 2018. p. 307-30.

19. Boardman J, Vandaele K, Evans R, Foster ID. Off-site impacts of soil erosion and runoff: why connectivity is more important than erosion rates. Soil Use Manag. 2019. https://doi.org/10.1111/sum.12496.

20. Bryan RB. Soil erodibility and processes of water erosion on hillslope. Geomorphology. 2000;32(3-4):385-415.

21. Cafiero C, Viviani S, Nord M. Food security measurement in a global context: the food insecurity experience scale. Measurement. 2018;116:146-52.

22. Chatrsimab Z, Ghavimi Panah MH, Vafaeinejad AR, Hazbavi Z, Boloori S. Prioritizing of the sub-watersheds using the soil loss cost approach (a case study; Selj-Anbar Watershed, Iran). Ecopersia. 2019;7(3):161-8.

23. Chehlafi A, Kchikach A, Derradji A, Mequedade N. Highway cutting slopes with high rainfall erosion in Morocco: evaluation of soil losses and erosion control using concrete arches. Eng Geol. 2019;260:105200.

24. Ciampalini R, Pastor A, Huard F, Follain S, Licciardello F, Crabit A et al. Modelling soil erosion under land use and climate change in a vineyard catchment of southern France. In: EGU general assembly conference abstracts, vol. 20; 2018. p. 17606.

25. Cole B, Smith G, Balzter H. Acceleration and fragmentation of CORINE land cover changes in the United Kingdom from 2006-2012 detected by Copernicus IMAGE2012 satellite data. Int J Appl Earth Obs Geoinf. 2018;73:107-22.

26. CORINE. CORINE: soil erosion risk and important land resources in the Southeastern regions of the European community. EUR 13233, Luxembourg, Belgium; 1992. p. 32-48.

27. Dengiz O, Akgül S. Soil erosion risk assessment of the Gölbaşı environmental protection area and its vicinity using the CORINE model. Turk J Agric For. 2005;29(6):439-48.

28. Dou Y, Yang Y, An S, Zhu Z. Effects of different vegetation restoration measures on soil aggregate stability and erodibility on the Loess Plateau China. CATENA. 2020;185:104294.

29. Dunne T, Malmon DV, Mudd SM. A rain splash transport equation assimilating field and laboratory measurements. J Geophys Res Earth Surf. 2010. https://doi.org/10.1029/2009JF001302.

30. Ellison WD. Soil detachment by water in erosion processes. Eos Trans Am Geophys Union. 1948;29(4):499-502.

31. El-Nady MA, Shoman MM. Assessment of soil erosion risk in the basin of wadi maged in northern west coast of Egypt using corine model and gis techniques. Assessment. 2017;32:33.

32. Fernández C, Fontúrbel T, Vega JA. Effects of pre-fire site preparation and post-fire erosion barriers on soil erosion after a wildfire in NW Spain. CATENA. 2019;172:691-8.

33. Fernandez HM, Martins FM, Isidoro JM, Zavala L, Jordán A Soil erosion, Serra de Grândola (Portugal). J Maps. 2016;12(5):1138-42.

34. Fletcher WJ, Hughes PD. Anthropogenic trigger for late Holocene soil erosion in the Jebel toubkal, high Atlas, Morocco. CATENA. 2017;149:713-26.

35. Foucher A, Evrard O, Chabert C, Cerdan O, Lefèvre I, Vandromme R, Salvador-Blanes S. Erosional response to land abandonment in rura areas of Western Europe during the Anthropocene: A case study in the Massif-Central, France. Agr Ecosyst Environ. 2019;284:106582.

36. García-Díaz A, Bienes R, Sastre B, Novara A, Gristina L, Cerdà A. Nitrogen losses in vineyards under different types of soil groundcover. A field runoff simulator approach in central Spain. Agric Ecosyst Environ. 2017;236:256-67.

37. Garnett T, Appleby MC, Balmford A, Bateman IJ, Benton TG, Bloomer P, et al. Sustainable intensification in agriculture: premises and policies. Science. 2013;341(6141):33-4.

38. Gaubi I, Chaabani A, Mammou AB, Hamza MH. A GIS-based soil erosion prediction using the revised universal soil loss equation (RUSLE) (Lebna watershed, Cap Bon, Tunisia). Nat Hazards. 2017:86(1):219-39. 
39. Ghanem S, Rukia A, Sulieman MM, Brevik EC, Mohammed S. Dataset on the Mediterranean soils from the coastal region of the Lattakia governorate, Syria. Data in brief. 2020;29:105254.

40. Gianinetto M, Aiello M, Polinelli F, Frassy F, Rulli MC, Ravazzani G, et al. D-RUSLE: a dynamic model to estimate potential soil erosion with satellite time series in the Italian Alps. Eur J Remote Sens. 2019;52(sup4):34-53.

41. Girmay G, Moges A, Muluneh A. Estimation of soil loss rate using the USLE model for Agewmariayam Watershed, northern Ethiopia. Agric Food Secur. 2020;9(1):1-12.

42. Gonzalez-Hidalgo JC, Pena-Monne JL, Luis M. A review of daily soil erosion in Western Mediterranean areas. CATENA. 2007;71:193-9.

43. Hajji $\mathrm{O}$, Abidi $\mathrm{S}$, Hermassi T, Mekni I. Evaluation of water erosion risk in Tunisian semi arid area. In: Water resources in arid areas: the way forward. Cham: Springer; 2017. p. 215-49.

44. Hosseini M, Keizer JJ, Pelayo OG, Prats SA, Ritsema C, Geissen V. Effect of fire frequency on runoff, soil erosion, and loss of organic matter at the micro-plot scale in north-central Portugal. Geoderma. 2016;269:126-37.

45. Hussien, M. (2014). A comparison study of the soil erosion under three ecosystems, (forests, burned forests, soil planted) Lattakia-Syria. Master thesis-Tishreen University. p. 110.

46. laaich H, Moussadek R, Baghdad B, Mrabet R, Douaik A, Abdelkrim D, Bouabdli A. Soil erodibility mapping using three approaches in the Tangiers province-Northern Morocco. Int Soil Water Conserv Res. 2016;4(3):159-67.

47. Issaka S, Ashraf MA. Impact of soil erosion and degradation on water quality: a review. Geol Ecol Landsc. 2017;1(1):1-11.

48. Jones JW, Antle JM, Basso B, Boote KJ, Conant RT, Foster l, et al. Toward a new generation of agricultural system data, models, and knowledge products: state of agricultural systems science. Agric Syst. 2017:155:269-88.

49. Kbibo I, Ibrahim J, Bou-Issa A. Studying the effect of soil erosion for eight different systems with different slopes in the coastal area under forests, burned forest and planted soil system. Tishreen Univ J Res Sci Stud Biol Sci Ser. 2017:39:25-38.

50. Keesstra SD, Bouma J, Wallinga J, Tittonell P, Smith P, Cerdà A, et al. The significance of soils and soil science towards realization of the United Nations Sustainable Development Goals. Soil. 2016;2(2016):111-28. https://doi.org/10.5194/soil-2-111-2016.

51. Kirchhoff M, MarzolffI, Seeger M, Hssaine AA, Ries JB. Erosion processes in overbrowsed argan woodlands, South Morocco. In: Geophysical Research Abstracts, vol. 21:2019.

52. Lal R. Soil erosion impact on agronomic productivity and environment quality. Crit Rev Plant Sci. 1998;17(4):319-464

53. Lanorte A, Cillis G, Calamita G, Nolè G, Pilogallo A, Tucci B, De Santis F. Integrated approach of RUSLE, GIS and ESA Sentinel-2 satellite data for post-fire soil erosion assessment in Basilicata region (Southern Italy). Geomatics Nat Hazards Risk. 2019;10(1):1563-95.

54. Le Bissonnais Y, Montier C, Jamagne M, Daroussin J, King D. Mapping erosion risk for cultivated soil in France. CATENA. 2002;46(2-3):207-20.

55. Mohammed SA, Fallah RQ. Climate change indicators in Alsheikh-Badr Basin (Syria). Geogr Environ Sustain. 2019;12(2):87-96.

56. Mohammed SA, Alkerdi A, Nagy J, Harsányi E. Syrian crisis repercussions on the agricultural sector: case study of wheat, cotton and olives. Regional Sci Policy Pract. 2020;12(3):519-37.

57. Mohammed S, Abdo HG, Szabo S, Pham QB, Holb IJ, Linh NTT, et al. Estimating human impacts on soil erosion considering different hillslope inclinations and land uses in the coastal region of Syria. Water. 2020;12(10):2786

58. Mohammed S, Al-Ebraheem A, Holb IJ, Alsafadi K, Dikkeh M, Pham $\mathrm{QB}$, et al. Soil management effects on soil water erosion and runoff in central Syria-a comparative evaluation of general linear model and random forest regression. Water. 2020;12(9):2529.

59. Mohammed S, Alsafadi K, Al-Awadhi T, Sherief Y, Harsanyie E, El Kenawy AM. Space and time variability of meteorological drought in Syria. Acta Geophys. 2020:68(6):1877-98.

60. Mohammed S, Alsafadi K, Enaruvbe GO, Harsányi E. Assessment of soil micronutrient level for vineyard production in southern Syria. Model Earth Syst Environ. 2021. https://doi.org/10.1007/s40808-021-01104-9.

61. Mohammed S, Alsafadi K, Talukdar S, Kiwan S, Hennawi S, Alshiehabi $\mathrm{O}$, et al. Estimation of soil erosion risk in southern part of Syria by using
RUSLE integrating geo informatics approach. Remote Sens Appl Soc Environ. 2020;20:100375.

62. Mohammed S, Hassan E, Abdo HG, Szabo S, Mokhtar A, Alsafadi K, et al. Impacts of rainstorms on soil erosion and organic matter for different cover crop systems in the western coast agricultural region of Syria. Soil Use Manag. 2020. https://doi.org/10.1111/sum.12683.

63. Mohammed S, Kbibo I, Alshihabi O, Mahfoud E. Studying rainfall changes and water erosion of soil by using the WEPP model in Lattakia Syria. J Agric Sci. 2016:61(4):375-86.

64. Mohammed S, Khallouf A, Alshiehabi O, Pham QB, Linh NTT, Anh DT, Harsányi E. Predicting soil erosion hazard in Lattakia governorate (W Syria). Int J Sediment Res. 2020. https://doi.org/10.1016/j.ijsrc .2020.06.005.

65. Naresh RK, Gupta RK, Minhas PS, Rathore RS, Dwivedi A, Purushottam VK, et al. Climate change and challenges of water and food security for smallholder farmers of Uttar Pradesh and mitigation through carbon sequestration in agricultural lands: an overview. IJCS. 2017;5(2):221-36.

66. Nearing MA, Yin SQ, Borrelli P, Polyakov VO. Rainfall erosivity: an historical review. CATENA. 2017;157:357-62.

67. Novara A, Pisciotta A, Minacapilli M, Maltese A, Capodici F, Cerdà A, Gristina $L$. The impact of soil erosion on soil fertility and vine vigor. A multidisciplinary approach based on field, laboratory and remote sensing approaches. Sci Total Environ. 2018;622:474-80.

68. Ochoa PA, Fries A, Mejía D, Burneo JI, Ruíz-Sinoga JD, Cerdà A. Effects of climate, land cover and topography on soil erosion risk in a semiarid basin of the Andes. CATENA. 2016;140:31-42.

69. Panagos $P$, Meusburger K, Van Liedekerke M, Alewell C, Hiederer R, Montanarella L. Assessing soil erosion in Europe based on data collected through a European Network. Soil Sci Plant Nutr. 2014;60(1):15-29.

70. Pappalardo SE, Gislimberti L, Ferrarese F, De Marchi M, Mozzi P. Estimation of potential soil erosion in the Prosecco DOCG area (NE Italy), toward a soil footprint of bottled sparkling wine production in different land-management scenarios. PLoS ONE. 2019;14(5):e0210922.

71. Pastor AV, Nunes JP, Ciampalini R, Koopmans M, Baartman J, Huard F, et al. Projecting future impacts of global change including fires on soil erosion to anticipate better land management in the forests of NW Portugal. Water. 2019;11(12):2617.

72. Plan Bleu. Threats to soils in Mediterranean countries, Plan Bleu Papers, Document Review; 2003. http://www.planbleu.org/publications/cahie rs2_sols_us.pdf.

73. Polyakov VO, Nearing MA, Stone JJ. Soil loss from small rangeland plots under simulated rainfall and run-on conditions. Geoderma. 2020;361:114070

74. Pretty J, Sutherland WJ, Ashby J, Auburn J, Baulcombe D, Bell M, et al. The top 100 questions of importance to the future of global agriculture. Int J Agric Sustain. 2010;8(4):219-36.

75. Quinton JN, Govers G, Van Oost K, Bardgett RD. The impact of agricultural soil erosion on biogeochemical cycling. Nat Geosci. 2010;3(5):311.

76. Reis M, Akay AE, Savaci G. Erosion risk mapping using CORINE methodology for goz watershed in kahramanmaras region, Turkey; 2016.

77. Reıs M, Dutal H, Bolat N, Savacı G. Soil erosion risk assessment using GIS and ICONA: a case study in Kahramanmaras. Turkey Gaziosmanpașa Üniversitesi Ziraat Fakültesi Dergisi. 2017;34(1):64-75.

78. Rodrigo-Comino J, Ponsoda-Carreres M, Salesa D, Terol E, Gyasi-Agyei Y, Cerdà A. Soil erosion processes in subtropical plantations (Diospyros kaki) managed under flood irrigation in Eastern Spain. Singapore J Trop Geogr. 2019;41:120-35.

79. Salesa D, Terol E, Cerdà A. Soil erosion on the "El Portalet" mountain trails in the Eastern Iberian Peninsula. Sci Total Environ. 2019;661:504-13.

80. Santeramo FG. Food security composite indices: implications for policy and practice. Dev Pract. 2015;25(4):594-600.

81. Santeramo FG. On the composite indicators for food security: decisions matter! Food Rev Int. 2015;31(1):63-73.

82. Santeramo FG, Lamonaca E. Objective risk and subjective risk: the role of information in food supply chains. Food Res Int. 2020;139:109962.

83. Santeramo FG, DiGioia L. La gestione del rischio in agricoltura: assicurazioni, credito e strumenti finanziari per lo sviluppo rurale. Bologna: Edagricole; 2018.

84. Sartori M, Philippidis G, Ferrari E, Borrelli P, Lugato E, Montanarella L, Panagos P. A linkage between the biophysical and the economic: 
assessing the global market impacts of soil erosion. Land Use Policy. 2019;86:299-312.

85. Sayah MA, Abdallah C, Khouri M, Nedjai R, Darwich T. Application of the Land Degradation Neutrality Concept in Mediterranean watersheds, a case study of Nahr Ibrahim, Lebanon. Geophysical Research Abstracts, vol. 21. 2019.

86. Seutloali KE, Dube T, Sibanda M. Developments in the remote sensing of soil erosion in the perspective of sub-Saharan Africa. Implications on future food security and biodiversity. Remote Sens Appl Soc Environ. 2018:9:100-6.

87. Skaf L, Buonocore E, Dumontet S, Capone R, Franzese PP. Applying network analysis to explore the global scientific literature on food security. Ecol Inf. 2020:56:101062.

88. Slimane AB, Raclot D, Rebai H, Le Bissonnais Y, Planchon O, Bouksila F. Combining field monitoring and aerial imagery to evaluate the role of gully erosion in a Mediterranean catchment (Tunisia). CATENA. 2018;170:73-83.

89. Smetanová A, Follain S, David M, Ciampalini R, Raclot D, Crabit A, Le Bissonnais Y. Landscaping compromises for land degradation neutrality: the case of soil erosion in a Mediterranean agricultural landscape. J Environ Manage. 2019;235:282-92.

90. Springmann M, Clark M, Mason-D'Croz D, Wiebe K, Bodirsky BL, Lassaletta $L$, et al. Options for keeping the food system within environmental limits. Nature. 2018;562(7728):519-25.

91. Springmann M, Mason-D'Croz D, Robinson S, Wiebe K, Godfray HCJ, Rayner M, Scarborough P. Mitigation potential and global health impacts from emissions pricing of food commodities. Nat Clim Change. 2017;7(1):69-74

92. Springmann M, Mason-D'Croz D, Robinson S, Garnett T, Godfray $\mathrm{HCJ}$, Gollin D, et al. Global and regional health effects of future food production under climate change: a modelling study. Lancet. 2016;387(10031):1937-46.

93. Sun W, Shao Q, Liu J, Zhai J. Assessing the effects of land use and topography on soil erosion on the Loess Plateau in China. CATENA. 2014;121:151-63.

94. Tayebi M, Tayebi MH, Sameni A. Soil erosion risk assessment using GIS and CORINE model: a case study from western Shiraz. Iran Arch Agron Soil Sci. 2017:63(8):1163-75.
95. Thorlakson T, Neufeldt H. Reducing subsistence farmers' vulnerability to climate change: evaluating the potential contributions of agroforestry in western Kenya. Agric Food Secur. 2012;1 (1):15.

96. UNCCD. United Nations Convention to Combat Desertification, Turkey's national action program on combating desertification, Ministry of Environment and Forestry Publication, n. 250; 2006. http://www.unccd int/actionprogrammes/northmed/national/2006/turkey-eng.pdf.

97. Vizzari M, Hilal M, Sigura M, Antognelli S, Joly D. Urban-rural-natural gradient analysis with CORINE data: an application to the metropolitan France. Landsc Urban Plan. 2018;171:18-29.

98. Welemariam M, Kebede F, Bedadi B, Birhane E. Effect of communitybased soil and water conservation practices on soil glomalin, aggregate size distribution, aggregate stability and aggregate-associated organic carbon in northern highlands of Ethiopia. Agric Food Secur. 2018;7(1):1-11.

99. Wilkinson $\mathrm{BH}, \mathrm{McEl}$ roy $\mathrm{BJ}$. The impact of humans on continental erosion and sedimentation. Geol Soc Am Bull. 2007;119:140-56.

100. Yavari S, Maroufpoor S, Shiri J. Modeling soil erosion by data-driven methods using limited input variables. Hydrol Res. 2018;49(5):1349-62.

101. Yuksel A, Gundogan R, Akay A. Using the remote sensing and GIS technology for erosion risk mapping of Kartalkaya dam watershed in Kahramanmaras Turkey. Sensors. 2008;8(8):4851-65.

102. Zhang KL, Shu AP, Xu XL, Yang QK, Yu B. Soil erodibility and its estimation for agricultural soils in China. J Arid Environ. 2008:72(6):1002-11.

103. Zhang S, Wang S, Yuan L, Liu X, Gong B. The impact of epidemics on agricultural production and forecast of COVID-19. China Agric Econ Rev. 2020;12(3):409-25.

104. Zhu M. Soil erosion risk assessment with CORINE model: case study in the Danjiangkou Reservoir region, China. Stoch Env Res Risk Assess. 2012;26(6):813-22.

105. Zuazo VHD, Pleguezuelo CRR. Soil-erosion and runoff prevention by plant covers: a review. In: Sustainable agriculture. Dordrecht: Springer; 2009. p. $785-811$

\section{Publisher's Note}

Springer Nature remains neutral with regard to jurisdictional claims in published maps and institutional affiliations.
Ready to submit your research? Choose BMC and benefit from:

- fast, convenient online submission

- thorough peer review by experienced researchers in your field

- rapid publication on acceptance

- support for research data, including large and complex data types

- gold Open Access which fosters wider collaboration and increased citations

- maximum visibility for your research: over $100 \mathrm{M}$ website views per year

At $\mathrm{BMC}$, research is always in progress.

Learn more biomedcentral.com/submissions 